НАУКОВИЙ ВІСНИК

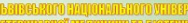

Cientific messegger of Livi National University
Veterinary Meedicine and Biotechnologies

now

औरा है है

1

- TERTES

Tом 21 № 91

2019

Науковий вісник Дьвівського національного університету ветеринарної медицини та біотехнологій імені С.3. Гжицького. Серія: Сільськогосподарські науки

Scientific Messenger of Lviv National University of Veterinary Medicine and Biotechnologies. Series: Agricultural sciences

UDC 636.082:636.16

\title{
Immunogenetic control of the origin of the Hutsul horse breed
}

S.S. Popadiuk

Stepan Gzhytskyi National University of Veterinary Medicine and Biotechnologies Lviv, Ukraine

Article info

Received 18.09.2019

Received in revised form 17.10 .2019

Accepted 18.10.2019

Stepan Gzhytskyi National University of Veterinary Medicine and Biotechnologies Lviv, Pekarskaya Str., 50, Lviv, 79010, Ukraine.

Tel.: +38-050-676-70-63

E-mail: breeding@lvet.edu.ua
Popadiuk, S.S. (2019). Immunogenetic control of the origin of the Hutsul horse breed. Scientific Messenger of Lviv National University of Veterinary Medicine and Biotechnologies. Series: Agricultural sciences, 21(91), 98-102. doi: 10.32718/nvlvet-a9117

The article analyzes the origin of horses of Hutsul breed, which gives an opportunity to make a certain idea about the genotypic features of animals. They were found to have specific features in the distribution of factors and alleles of the D-system of blood groups. An individual analysis of the genotypes of Hutsul horses shows that their diversity is quite significant. Generally, genotypes occur that combine the dghm allele with the cgm and bcm alleles. At the individual level, animal testing materials for blood groups create an information base to study the genetic structure of a population. Analysis of the genetic structure of the herd shows its considerable variability. It was found 9 alleles in the herd with a frequency from 0.014 to 0.264 . The most common alleles are de; sgm, with frequencies of 0.264 and 0.220 respectively. The saturation of the herd with these alleles is primarily related to the genotypes (de/cgm) of the stallions used by Vulcan and Centaur. The degree of homogeneity of the flock gene pool is characterized by a homozygosity coefficient (CA) of 0.173 and indicates the theoretically expected frequency of homozygous genotypes in panmyxia, that is, the absence of directed selection of parental pairs in the same number of females and males. Although the herd does not meet the requirements of panmyxia, there is a clear deficiency in homozygotes. In general, immunogenetic studies provide grounds for organizing a breeding process for the reconstruction of the Hutsul breed gene pool with the restoration of its inherent qualities, which will enable it to obtain competitive breeding products. The study of the structure of the population provides material for the analysis of genetic processes occurring at certain stages of the breeding process as a result of the use of different breeding methods. The results of the testing, which is still limited by the number of horses of the Hutsul breed, form the basis for further systematic application of genetic marking in the work on the formation of the Hutsul breed in the Ukrainian Carpathian region.

Key words: immunogenetic control, factors of blood groups, alleles of system D of blood groups, genetic similarity, hereditary information, genotype, coefficient of homozygosity.

\section{Імуногенетичний контроль достовірності походження гуцульської породи коней}

\author{
С.С. Попадюк
}

Львівський національний університет ветеринарної медицини та біотехнологій імені С.3. Гжицького, м. Львів, Украӥна

У статті проведено аналіз з достовірності походження коней гуиульської породи, що дає можливість скласти певне уявлення про генотипові особливості тварин. Встановлено, щзо вони мають специфічні ознаки за розподілом факторів та алелей D-системи груп крові. Індивідуальний аналіз генотипів гуиульських коней свідчить про досить значну ёх різноманітність. Найчастіше трапляються генотипи, які поєднують алель dghm з алелями сgт i bcm. На індивідуальному рівні матеріали тестування тварин за групами крові створюють інформачійну базу для дослідження генетичної структури популячії. Аналіз генетичної структури стада свідчить про його досить значну мінливість. В стаді знайдено 9 алелів з частотою від 0,014 до 0,264. Найбільш розповсюджені алелі de; cgm, з частотами відповідно 0,264 i 0,220. Насичення стада ичми алелями пов'язано насамперед з генотипами (de/cgm) використовуваних жеребиів Вулкана і Кентавра. Ступінь однорідності генофонду стада характеризує коефіцієнт гомозиготності (Са), який дорівнює 0,173 і вказує на теоретично очікувану частоту гомозиготних генотипів при 
панміксї, тобто відсутності спрямованого підбору батьківських пар за однакової кількості самок $і$ самиів. Хоч стадо не відповідає вимогам панміксї, але щчодо гомозигот в ньому спостерігається явний дефіцит. Загалом проведені імуногенетичні дослідження дають підстави для організаиії селекиійного проиесу із реконструкиії генофонду гуиульської породи з відновленням притаманних їй якостей, що дасть змогу одержати конкурентноздатну племінну продукцію. Дослідження структури популяиії дає матеріал для аналізу генетичних процесів, щзо відбуваються на певних етапах селекиійного процесу в результаті застосування різних методів розведення. Результати проведеного тестування поки ше обмеженого за кількістю поголів'я коней гуиульської породи створює базу для подальшого системного застосування генетичного маркірування в роботі з формування масиву гуиульської породи в регіоні Украӥнських Карпат.

Ключові слова: імуногенетичний контроль, фактори груп крові, алелі системи D груп крові, генетична схожість, спадкова інформація, генотип, коефіцієнт гомозиготності.

\section{Вступ}

На даний час зростає актуальність раціонального використання генетичних ресурсів, притаманних локальним породам, комплексу генів, які забезпечують їхню адаптаційну пластичність, пристосованість до конкретних умов утримання і експлуатації (Vinnichuk et al., 1991; Lisovyi et al., 2000; Tkachova, 2015). B цьому плані має значення об’єктивна оцінка якостей, які притаманні аборигенним породам і забезпечують їхню конкурентоспроможність. Такою породою $\epsilon$ гуцульська для Карпатського регіону України (Stefurak, 1998; Popadiuk, \& Dzitsiuk, 2002; Marchuk, \& Lavryniuk, 2016; Romanenko, 2018). 3 цієї точки зору актуальним завданням є всебічне дослідження племінних ресурсів і вирішення питання раціонального використання, а також формування масиву гуцульської породи коней в Україні

\section{Матеріал і методи досліджень}

Дослідження проводились на поголів'ї коней гуцульської породи фермерського господарства “Золота підкова” Ужгородського району Закарпатської області (34 голів). Матеріалом для імунологічного аналізу послужили проби переферійної крові коней, яку брали зранку, до годівлі і напування.

Тестування тварин за 12 факторами груп крові (Da, $\mathrm{Db}, \mathrm{Dc}, \mathrm{Dd}, \mathrm{De}, \mathrm{Df}, \mathrm{Dh}, \mathrm{Dk}, \mathrm{Dm})$ здійснювали, в лабораторії генетичних основ селекції Інституту розведення і генетики тварин імені М.В. Зубця НААН, постановкою реакції прямої аглютинації за методичними вказівками Дубровської (Dubrovskaja, 1983), 3 використанням моноспецифічних сироватокреагентів, виготовлених в лабораторії імуногенетики та ідентифікованих $з$ міжнародними еталонами.

\section{Результати та їх обговорення}

Кожна порода характеризується властивими їй біологічними i господарськими особливостями, що формуються в певних умовах середовища і зумовлені спадковістю тварин (Tkachova, 2019). Породи сільськогосподарських тварин складаються 3 різнорідних особин зі складною спадковою різноманітністю, а також природного і штучного добору, вони відрізняються одна від одної за генетичною структурою. Породи як системи спадкових форм є складовими части- нами безперервного селекційного процесу (Stoianov et al., 2000; Sokolova et al., 2015).

Завдання щодо ефективного використання племінних ресурсів коней вирішується шляхом поєднання селекційних і генетичних методів досліджень.

В реальному селекційному процесі одним 3 генетичних методів, який знаходить систематичне застосування, $\epsilon$ імуногенетичний контроль достовірності походження племінних тварин. Цей контроль згідно 3 Законом “Про племінну справу у тваринництві" $\epsilon$ одним 3 елементів ідентифікації тварин. Основне завдання, яке вирішується при здійсненні контролю походження, полягає в підтвердженні достовірності записів про батьків тварини.

При контролі за групами крові порівнюють типи крові батька, матері і їхнього нащадка. У останнього повинні бути тільки ті фактори груп крові, що є хоч би в одного з батьків. Більш детальний і поглиблений імуногенетичний контроль походження проводиться за алелями системи D груп крові. В цьому випадку можливий неповний сімейний аналіз, за яким визначається наявність у потомна одного 3 двох альтернативних алелів батька.

Результати повного сімейного аналізу в фермерському господарстві “Золотій підкові” 3 підтвердженням походження наведені нижче (табл. 1).

Контроль походження жеребців Бубен 027, Мудрий 019, кобила Міра 023 і Чайка 036 засвідчує достовірність їхнього походження за даними родоводів від жеребця Вулкан і відповідних матерів. Імуногенетичним аналізом встановлено, що Міра 023 і Чайка 036 від свого батька одержали алель cgm, а Мудрий 019 i Бубен 027 одержали альтернативний алель de.

За результатами проведеного при контролі походження імуногенетичного аналізу можна констатувати, що напівсибси Бубен 027 і Мудрий 019 мають генетичну схожість за генетичним матеріалом, що маркірується алелем $\mathrm{D}^{\mathrm{de}}$, а Мipa 023 і Чайка 036 відрізняються від них за цією спадковою інформацією.

Таким чином, за інформацією, яка покладена в основу контролю достовірність походження, є можливість скласти певне уявлення про генотипові особливості тварини.

Таким аналізом можна охопити всіх нащадків плідника, що протестоване за групами крові, тобто до деякої міри провести аналіз його генотипу за відповідними алелями. 
Таблиця 1

Експертиза походження коней в фермерському господарстві “‘Золота підкова’

\begin{tabular}{|c|c|c|c|c|c|}
\hline \multirow{2}{*}{$\begin{array}{c}\text { Родинні } \\
\text { відносини }\end{array}$} & \multirow{2}{*}{$\begin{array}{c}\text { Кличка, } \\
\text { номер }\end{array}$} & \multicolumn{3}{|c|}{ Генетичні системи груп крові } & \multirow{2}{*}{$\begin{array}{c}\text { Висновок про похо- } \\
\text { дження }\end{array}$} \\
\hline & & $\mathrm{A}$ & 5 & $\mathrm{~K}$ & \\
\hline Батько & Вулкан & $a d /$ & $\mathrm{cgm} / \mathrm{de}$ & $-/-$ & \\
\hline Мати & Миша & $a d /$ & $\mathrm{bcm} / \mathrm{de}$ & $-/-$ & \\
\hline Син & Бубен 027 & $a d /$ & cgm/ad & $-/-$ & Батьки дійсні \\
\hline Мати & Медея & $-/-$ & $\mathrm{cfm} / \mathrm{ad}$ & $-/-$ & \\
\hline Син & Мудрий & $\mathrm{ad} /-$ & $\mathrm{de} / \mathrm{cfm}$ & $-/-$ & Батьки дійсні \\
\hline Мати & Мyха & $-/-$ & $\mathrm{de} / \operatorname{cghm}$ & $-/-$ & \\
\hline Дочка & Mipa & $\mathrm{ad} /-$ & $\operatorname{cgm} / \mathrm{de}$ & $-/-$ & Батьки дійсні \\
\hline Мати & Чайка 006 & & $\mathrm{bcm} / \mathrm{de}$ & $-/-$ & \\
\hline Дочка & Чайка 036 & & $\operatorname{cgm} / \mathrm{de}$ & $-/-$ & Батьки дійсні \\
\hline
\end{tabular}

Таблиця 2

Аналіз генотипів жеребця Вулкана за алелями системи D груп крові

\begin{tabular}{|c|c|c|c|}
\hline Родинні відносини & Кличка, номер & Алелі системи D груп крові & Масть \\
\hline Батько & Вулкан & $\mathrm{cgm} / \mathrm{de}$ & сіра в гречку \\
\hline Дочка & Mipa 023 & $\mathrm{cgm} / \mathrm{de}$ & каракова \\
\hline Дочка & Білоп’ятка 021 & $\mathrm{cgm} / \mathrm{cfm}$ & сіра в гречку \\
\hline Дочка & Гречка 020 & $\mathrm{cgm} / \mathrm{dgm}$ & гніда \\
\hline Дочка & Чайка 036 & $\mathrm{cgm} / \mathrm{de}$ & гніда \\
\hline Син & Бубен 027 & $\mathrm{de} / \mathrm{cgm}$ & мишаста \\
\hline Син & Мудрий 019 & $\mathrm{de} / \mathrm{cfm}$ & гніда \\
\hline Дочка & Ельза 017 & $\mathrm{de} / \mathrm{bcm}$ & бура \\
\hline Дочка & Зірка 028 & $\mathrm{de} / \mathrm{de}$ & мишаста \\
\hline Дочка & Лаванда 032 & $\mathrm{de} / \mathrm{cgm}$ & руда \\
\hline
\end{tabular}

Так, у жеребця Вулкан з 9 нащадків 4 успадкували алель сqт, а п’ятьма був успадкований алель батька de (табл. 2).

Якщо аналіз генотипу Вулкана здійснювати за виявленням зв'язків альтернативних алелів 3 іншими ознаками, то з тих ознак, що наочно можна зафіксувати у нащадків Вулкана, найбільш доступною є масть. Різноманітність масті у нащадків цього жеребця, як і в усій породі, не дає підстав для того щоб вважати алелі системи D груп крові маркерами цієї ознаки. Проведення аналізу генотипів плідників в гуцульській по- роді за іншими ознаками потребує накопичення більшого обсягу імуногенетичної та фенотипової інформації.

Інші більш доступні можливості аналізу генотипів пов'язані з наявністю імуногенетичної інформації в декількох поколіннях. Такий аналіз руху генетичної інформації жеребця Кентавра ілюструє схема (рис. 1).

В цій схемі штрихуванням позначені різні алелі, які у відповідних напівквадратах (для жеребців) або напівколах (для кобил) розміщуються ліворуч ті, що отримані від матері, праворуч - отримані від батька.

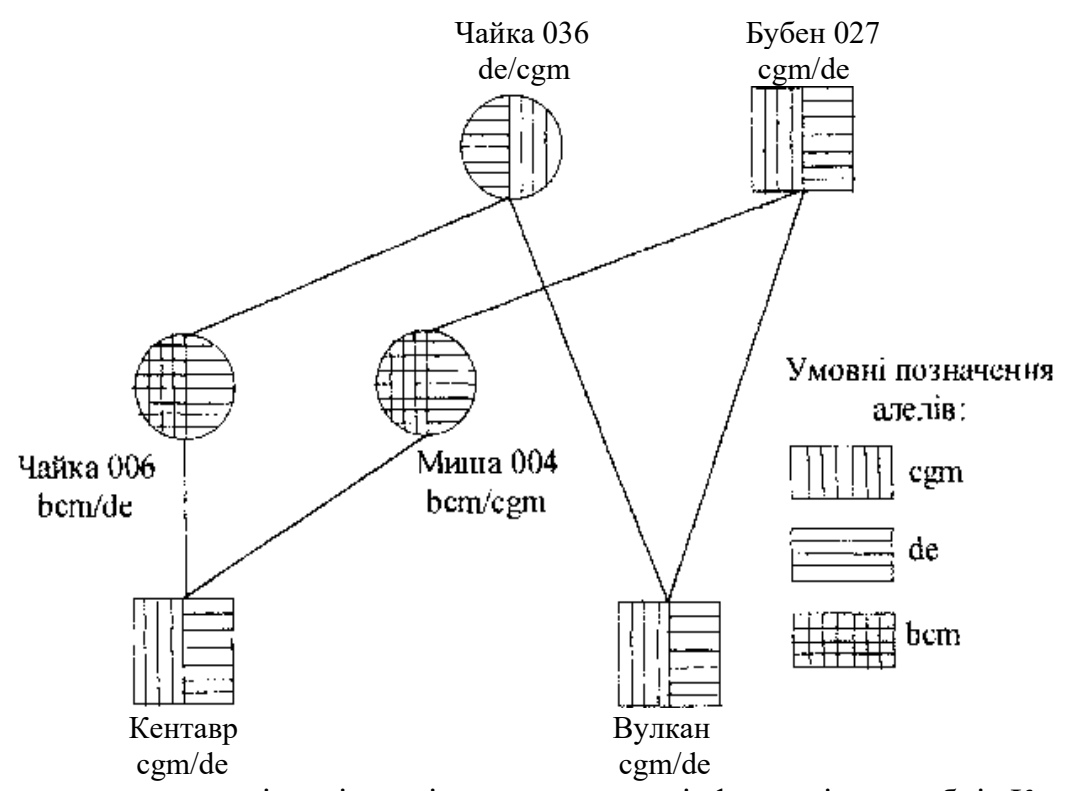

Рис. 1. Схема успадкування алелів, які маркірують спадкову інформацію жеребців Кентавра і Вулкана 
Простежуючи за передачею алелів Кентавра, можна відзначити розщеплення його генотипу в першому поколінні, де напівсестри за батьком кобили Чайка 006 і Миша 004 успадкували різні алелі батька (de i cgm).

Відповідно нащадків цих кобил успадкували алелі, які маркірують генетичний матеріал їхнього діда (cgm i de). Отже, з одного боку, ці нащадки (кобила Чайка 006 і Бубен 027) мають генетичну спільність з своїм дідом за спадковою інформацією, яка маркірується алелем системи D груп крові. 3 іншого боку, можна стверджувати, що у цих тварин генотипи за системою $\mathrm{D}$ груп крові ідентичні, але вони маркірують різний генетичний матеріал, тому що алель de Чайка 036 одержала від матері Чайки 006, а Бубен 027 - від Миші 004.

Крім імуногенетичного аналізу на індивідуальному рівні, матеріали тестування тварин за групами крові створюють інформаційну базу для дослідження генетичної структури популяцій. Аналіз генетичної структури стада фермерського господарства “Золота підкова” за алелями D системи груп крові свідчить про його досить значну мінливість (табл. 3).

\section{Таблиця 3}

Генетична структура коней фермерського господарства “Золота підкова" за алелями D-системи груп крові, n = 34

\begin{tabular}{ccc}
\hline Алелі & Кількість носіїв & Генна частота \\
\hline ad & 5 & 0,088 \\
bcm & 7 & 0,120 \\
cegm & 4 & 0,055 \\
cfm & 4 & 0,055 \\
cghm & 2 & 0,028 \\
cgm & 15 & 0,220 \\
de & 18 & 0,264 \\
dghm & 11 & 0,161 \\
dk & 1 & 0,014 \\
Коефіцієнт & & 0,173 \\
гомозиготності & & \\
\hline
\end{tabular}

В стаді знайдено 9 алелів з частотою від 0,014 до 0,264. Найбільш розповсюджені алелі de; cgm, 3 частотами відповідно 0,264 і 0,220. Насичення стада цими алелями пов'язано, насамперед 3 генотипами (de/cgm) використовуваних жеребців Вулкана і Кентавра. Ступінь однорідності генофонду стада характеризує коефіцієнт гомозиготності (Ca), який обчислений як сума квадратів генних частот всіх виявлених алелів. Цей коефіцієнт у стаді дорівнює 0,173 і вказує на теоретично очікувану частоту гомозиготних генотипів при панміксії, тобто відсутності спрямованого підбору батьківських пар за однакової кількості самок і самців. Хоч стадо не відповідає вимогам панміксії, але щодо гомозигот в ньому спостерігається явний дефіцит (табл. 4).

В стаді виявлено всього дві гомозиготні кобили Медея 008 (генотип ad/ad) i Зірка 028 (генотип de/de).

\section{Таблиця 4}

Генотипи тварин за алелями D-системи груп крові коней фермерського господарства “Золота підкова", $\mathrm{n}=34$

\begin{tabular}{ccc}
\hline Генотипи & Кількість тварин & Частота, \% \\
\hline$a d / a d$ & 1 & 2,94 \\
$a d / c f m$ & 2 & 5,88 \\
$a d / c g m$ & 1 & 2,94 \\
$a d / d e$ & 1 & 2,94 \\
$b c m / c g m$ & 2 & 5,88 \\
$b c m / d e$ & 5 & 14,70 \\
$c e g m / c g m$ & 3 & 8,82 \\
$c e g m / d g h m$ & 1 & 2,94 \\
$c f m / c g m$ & 1 & 2,94 \\
$c f m / d e$ & 1 & 2,94 \\
$c g h m / d g h m$ & 2 & 5,88 \\
$c g m / d e$ & 4 & 11,76 \\
$c g m / d g h m$ & 4 & 11,76 \\
de/de & 1 & 2,94 \\
de/dghm & 4 & 11,76 \\
de/dk & 1 & 2,94 \\
\hline
\end{tabular}

Дефіцит гомозигот частково пов'язаний з особливостями підбору, з використанням неспоріднених 3 тваринами стада жеребців. 3 іншого боку, очевидно, в гуцульській породі діють генетичні процеси, що протидіють звуженню генетичної мінливості, механізми яких можуть бути аналогічні встановленим в стаді сірої української верхової породи. Звичайно, кількості випадків повного сімейного аналізу по стаду замало для одержання вірогідних висновків, та все ж $з$ трьох випадків теоретично очікуваного одержання гомозигот (див. табл. 3) фактично не було одержано жодного гомозиготного генотипу (очікувалось 3 вірогідністю 0,5 одержання гомозигот при підборі до Вулкана: cgm/cgm - Бубен 027, фактично cgm/de; de/de -Mipa 023, фактично cgm/de; de/de-Чайка 036, фактично $\mathrm{cgm} / \mathrm{de})$.

Найбільше в стаді тварин генотипів bcm/de (14,70\%), cgm/de (11,76\%) i cgm/dghm (11,76\%), de/dghm (11,76\%). Закономірно, що в сімох 3 шістнадцяти знайдених в стаді генотипів D алель de, а носіями його є половина тварин стада.

Імуногенетичний аналіз показав, що коні гуцульської породи мають специфічні особливості за розподілом факторів та алелей D-системи груп крові.

\section{Висновки}

За результатами проведених досліджень обгрунтовані методичні підходи і організаційно-методичні засади селекційно-генетичного моніторингу з розведення гуцульської породи, які покликані забезпечити не тільки збереження, а й реконструкцію і розширене відтворення генофонду породи, що дасть змогу одержати конкурентноздатну племінну продукцію.

Перспективи подальших досліджень. Таким чином, аналізом при контролі походження не обмежується застосування імуногенетичних методів в племінній роботі. Дослідження структури популяції дає матеріал для аналізу генетичних процесів, що відбуваються на певних етапах селекційного процесу в 
результаті застосування різних методів розведення. Результати проведеного тестування поки що обмеженого за кількістю поголів'я коней гуцульської породи створює базу для подальшого системного застосування генетичного маркірування в роботі з формування масиву гуцульської породи в регіоні Українських Карпат.

\section{References}

Dubrovskaja, R.M. (1983). Metodicheskie ukazanija po izgotovleniju syvorotok-reagentov dlja opredelenija grupp krovi i ispol'zovaniju ih pri kontrole proishozhdenija loshadej. M.: Kolos (in Russian).

Lisovyi, F., Slesarev, O., \& Verchuk, P. (2000). Shliakhy zberezhennia vysokotsinnoho vitchyznianoho henofondu pleminnoho tvarynnytstva. Tvarynnytstvo Ukrainy, 5-6, 2-4 (in Ukrainian).

Marchuk, O.O., \& Lavryniuk, O.O. (2016). Osoblyvosti hodivli konei hutsulskoi porody. Visnyk ZhNAEU, 2(56), 286-292. http://ir.znau.edu.ua/handle/ $123456789 / 7627$ (in Ukrainian).

Popadiuk, S.S., \& Dzitsiuk, V.V. (2002). Hutsulska poroda konei v Ukraini. Naukovyi visnyk. Lviv, 4(1), 139-142 (in Ukrainian).

Romanenko, G.V. (2018). Istorychni aspekty rozvedennia ta zberezhennia porody hutsulskykh konei na ukrainskykh zemliakh u skladi Polshchi v mizhvoiennyi period [Historical aspects of breeding and preservation of Hutsul horse breed on the Ukrainian territory of the interwar Poland]. Scientific and theoretical almanac "Grani", 21(9), 81-89. doi: 10.15421/1718118.

Sokolova, G.A., Kovalchuk, N.A., \& Popadyuk, S.S. (2015). Exterior and workability ukrainian horse breed under different lines pjsc "Rise-Maksymko". Scientific Messenger of LNU of Veterinary Medicine and Biotechnologies. Series: Agricultural Sciences, 17(1), 210-214. https://nvlvet.com.ua/index.php/ agriculture/article/view/3578 (in Ukrainian).

Stefurak, Yu.P. (1998). Hutsulska poroda konei. Stan i perspektyvy rozvytku. Rakhiv. Ukraina, 1, 252-256 (in Ukrainian).

Stoianov, R.O., Osadcha, L.V., Holovach, M.I., \& Popadiuk, S.S. (2000). Imunohenetychna kharakterystyka konei hutsulskoi porody. Rozvedennia i henetyka tvaryn, 33, 143-148 (in Ukrainian).

Tkachova, I.V. (2015). Metody selekcii porod loshadej s ogranichenym genofondom. Sovremennye tehnologi sel'-s'kohozjajstvennogo proizvodstva: sb. nauch. st.. po mat. HVII Mezhdunar. nauch.-prak. konfer. Grondo: GGAU, 122-125 (in Russian).

Tkachova, I.V. (2019). Systema selektsiinoho udoskonalennia zavodskykh porid konei v umovakh obmezhenoho henofondu. Avtoref. dys.. na zdob. stupenia doktora s.-h. nauk. s. Chubynske (in Ukrainian).

Vinnichuk, D.T., Podoba, B.E., \& Efimenko, M.Ja. (1991). Isledovanie geneticheskih markerov dlja ocenki i poluchenija zhivotnyh zhelatel'nogo tipa. Citologija i genetika, 6, 51-55 (in Russian). 